\title{
The Nexus between Project Monitoring and Evaluation and Quality of Residential Buildings in Nairobi County, Kenya
}

\author{
Dr. Mwenda, Mary Nyawira ${ }^{1}$, Dr. Otieno- Omutoko Lillian², Prof. Christopher Gakuu ${ }^{3}$. \\ ${ }^{1}$ Lecturer, Department of Open Learning, University of Nairobi, Thika, Kenya \\ ${ }^{2}$ Senior Lecturer, Department of Open Learning, University of Nairobi, Nairobi, Kenya \\ ${ }^{3}$ Director, School of Open, Distance and e-Learning, University of Nairobi, Nairobi, Kenya
}

\begin{abstract}
Integrating monitoring and evaluation within project construction phases is considered in this research a means by which construction of buildings can foster sustainable development and alleviate their collapse as witnessed in many countries. The aim of monitoring and evaluation is to provide information that can help inform decisions, improve performance and achieve planned results. Projects with strong monitoring and evaluation components tend to stay on track. Additionally, problems are often detected earlier, which reduces the likelihood of risks, major cost overruns or time delays. Against this backdrop, this research sought to analyze the influence of project monitoring and evaluation on quality of buildings. Descriptive survey and correlational research designs were used in a mixed methods research approach. Quantitative data was collected through a questionnaire while qualitative data was collected through an interview guide. Research instruments were pilot tested for validity through content related method and reliability through split- half criterion. A sample of 192 respondents was selected by use of Yamane's (1967) sampling size formula from a population of 3475 registered contractors in Nairobi County by May 2017. A census survey was conducted among the 67 engineering consultants and 24 officers in top management teams of NCA and NBI. Arithmetic mean and standard deviation were used for analyzing descriptive data while Pearson Product Moment Correlation (r) and regression analysis $\left(\mathbf{R}^{2}\right)$ were used for analyzing inferential data. $F$-tests were used to test the hypothesis in the study. Tests of statistical assumptions were carried out before data analysis to avoid invalidation of statistical analysis. With $r=0.409, R^{2}=0.167, F$ $(1,222)=49.770$ at $p=0.000<0.05$, the null hypothesis was rejected and it was concluded that there is a positive relationship between ethical concerns in project monitoring and evaluation and quality of buildings. It is recommended that project implementation process should be overseen by a competent consultant to ensure good supervision and all necessary amendments be done at the right time and in an appropriate way to ensure successful project delivery.
\end{abstract}

Key words: building projects, construction projects, contractors, monitoring and evaluation, quality

\section{INTRODUCTION}

$\mathrm{M}$ onitoring and evaluation serve several purposes. In the absence of effective monitoring and evaluation, it would be difficult to know whether the intended results are being achieved as planned, what corrective action may be needed to ensure delivery of the intended results, and whether initiatives are making positive contributions towards human development (UNDP, 2009).

In a study to examine factors affecting project performance in developing countries, Faridi and El-Sayegh (2006) reported that shortage of skills of manpower, poor supervision and poor site management, unsuitable leadership, shortage and breakdown of equipment among others contribute to substandard projects in the United Arab Emirates. Hansonet al. (2003) examined causes of client dissatisfaction in the South African building industry and found that conflict, poor workmanship and incompetence of contractors were among the factors which would adversely affect project performance. Mbachu and Nkando (2007) established that quality and attitude to service was one of the key factors undermining successful project delivery in South Africa. Effects of such unethical malpractices have been witnessed in many countries. Seemingly firm structures all over the world have cracked, split, and disintegrated right beneath people's feet.

A case in point is that in New Delhi, India where on November 15, 2010, the rains pounded on a poorly constructed building and tragically claimed 67 lives. The building housed 400 low income migrant labourers from rural sections of eastern India (Hutchinson, 2014).Similarly, on January 26, 2012, a 20-storey building in Rio de Janeiro, Brazil spontaneously collapsed. The gigantic high-rise crashed into another ten-storey building and a smaller three storey building, reducing all three structures to one huge pile of rubble, killing at least 17 people. Authorities suggested that illegal construction work had weakened the 20 -storey building and caused it to collapse, which triggered a chain reaction and brought down the two smaller buildings. This catastrophe led Brazilian authorities to call for reforms and more vigilant building regulations.

In construction, some of the key participants involved in the monitoring and evaluation of projects include contractors, clients or project owners and consultants (Alsagour, 2014). Contractors are greatly responsible for implementing 
whatever works is within the contract agreement (Enshassi, 1996). They liaise with consultants in the monitoring and evaluation of projects to ensure that they are delivered within the parameters of time and cost and to the required performance standards. If the work is of sound quality, then the contractor should be allowed to move on to the next phase. Moreover, these parties experience situations warranting moral reasoning with subsequent impact on the construction work

In case the project delays beyond the time limit provided in the work schedule, the contractor should devise a new work plan, but only if the delay is beyond the contractor's control (IUCN, 2000). However, if the contractor's fault causes the delay, then the contract will be dismissed and a new one is negotiated. Control should be conducted form phase to phase to ensure quality standards are attained. This is important in order to ascertain that quality and tasks performed throughout the project are according to specification and owner's expectations. The quality element is essential in every component of construction activities that acts as a guarantee to ensure the project achieves the highest standard specified by the owner.

\subsection{Statement of the Problem}

Kenya has witnessed a surging number of constructed residential buildings whose quality dimension has been compromised. Several cases of collapsed buildings have been reported in many places such as Huruma, Nyali, Nairobi's Spring Valley estate and Nairobi's Westland area, among others (NCA Interim Report, 2016). These collapses were reportedly attributed to, among others, poor design and supervision, poor materials and substandard workmanship. Others are columns failure due to bending, concrete not meeting the minimum strength for structural elements, lack of proper and regular supervision, lack of maintenance, poor quality materials, non-approval of works and lack of professional input during supervision. The list is endless but points a finger at inadequate or lack of documented policies, systems, processes, and procedures that can help the county governments and other construction sector regulators to manage the way they operate, make compliance assessments, make decisions and manage risk. According to the Kenya Accreditation Service (2015-2016), the possible causes of collapsing building structures are inadequate geotechnical and materials investigations, use of inappropriate specifications, incompetent design, poor workmanship, lack of ethics, poor supervision, misunderstanding between parties to the contract, use of inappropriate materials and unskilled workers. This is a clear indication that important considerations were not adhered to during the monitoring and evaluation processes of these buildings, despite continued effort by National Construction Authority to regulate contractors by enacting laws that would promote the Kenyan construction industry.

The above causes constitute some of the main activities that are part and parcel of the process of inspection of buildings from plan approval, inspection of materials, testing and construction activities. Monitoring and evaluation would go far in ensuring these activities are well conducted. This means that embracing and entrenching building inspections as part of the construction, maintenance and statutory regulations of buildings will greatly reduce or eliminate altogether the occurrence of buildings collapsing thereby ensuring quality of residential buildings. It is against this background that this research studies the influence of project monitoring and evaluation on quality of residential buildings in Kenya.

\subsection{Objective of the Study}

The objective of this study was to assess how monitoring and evaluation influences quality of residential building construction projects in Nairobi County.

\subsection{Hypothesis of the study}

The following Null Hypothesis was tested:

Ho: There is no significant influence of monitoring and evaluation on quality of residential building construction projects in Nairobi County.

\section{LITERATURE REVIEW}

\subsection{Quality of Building Construction Projects}

There is no precise or single definition of 'quality', although many of the pioneers of the quality movement and gurus, such as Deming, Juran, Crosby, Feigenbaum, Taguchi and others, had their own individual definitions of 'quality'. Edwards Deming referred to quality as a predictable degree of uniformity and dependability with a quality standard suited to the customer (Chandrupatla, 2014). According to Rumane (2011), a construction company needs to demonstrate its ability to consistently provide products that meet or exceed customer expectations and satisfaction, while also adopting appropriate processes for the continued improvement of the Quality Management System and related assurances of conformity to customer and applicable regulatory requirements.

Ethical standards according to Sambasivan and Soon (2007) are required in the various construction processes to ensure quality of a project such as in project definition, activity sequencing and determining of activity duration. Failure to adhere to ethical guidelines may therefore affect the project completion time. Transparency International (2005a) argued that corruption if allowed to persist undermines the quality and quantity of services. It corrodes economic development and jeopardizes the provision of basic public goods and services especially in developing countries.

\subsection{Monitoring and Evaluation and Quality of Residential Buildings}

Monitoring and evaluation of construction is an important process of the project life cycle. The need to observe or monitor construction processes to ensure quality work cannot 
be overemphasized. Enshassi (1996) stresses on the need to observe projects promptly and at regular intervals. IUCN (2000) pointed out that regular monitoring of project progress will concentrate greater effort on the set output indicators and targets. This is of great significance in the attainment of quality and customer satisfaction. Where deviations from the expected results are noted, effort is made to correct them and this should be done on a regular basis.

Management Audits and Reviews of Projects are necessary. A project audit is a systematic and independent investigation to check if the project is performing correctly with respect to project and/ or project management standards. A project review is defined as a formal examination of the project by persons with authority in order to see whether improvement or correction is needed (Huemann, 2004). An accreditation is an external evaluation based on defined and public known standards. Accreditation was originally established to support customer protection. Consumers can be protected by certification, inspection, and testing of products and by manufacturing under certified quality systems. Consumers need confidence in the certification, inspection, and testing work carried out on their behalf, but that they cannot check for themselves (Huemann, 2004). Quality control should be continuous, commencing from the moment the project initiates to the final steps in the project closure phase (PM4DEV, 2016). There are many instances where a project can be progressing smoothly right up until the moment that a quality issue becomes apparent. The key to project success is identifying such issues well before they become obvious because once this happens it is virtually impossible to meet the original requirements (Newton, 2015).

Almost all of the processes that form part of project management will involve meetings between the project manager, the team and other stakeholders. How well these meetings are conducted will have a major impact on how smoothly the project runs. Collective decision-making is a very important area of project management that can make or break this part of the project (Newton, 2015). Collective decision-making allows the team members come up with performance evaluation measures to be utilized to gauge the level of project success. The evaluation of process performance can help find questions in the enforcement of construction projects, determining the reasons for the questions and correcting the errors in the practice in time to improve management's performance of construction project (Bai and Yang 2011).

Competence of monitoring consultants determines quality of construction work. Shakantu (2006) identified negligence in the form of poor quality works and also covering up poor workmanship during site operation as some of the unethical practices at construction stage. Bowen et al. (2007) defined negligence as lack of proper care and attention or carelessness. Vee and Skitmore (2003) on the other hand defined negligence as a failure to exercise that degree of care which, in the circumstances, the law requires for the protection of those interests of other persons which may be injuriously affected by the want of such care. Professionally, this would be the failure to exercise the degree of care considered reasonably warranted by the circumstances, resulting in an unintended injury to another party.

Lack of efficient procurement highly affects development issues such as service delivery, economic growth, private sector development and decentralization (Kerry \& Phoebe, 2006). In addition, inefficient procurement adversely affects professionalism and international trade and investment. Public procurement is challenged to make savings by improving efficiency. Standards can enable procuring entities and suppliers to work together so that they share the advantages of innovation and collaboration (BSI group, 2008). Efficiency and value for money is delivered through the whole procurement cycle, from planning stage to contract management stage.

According to Mawenya (2008), the level of efficiency in public procurement is basically measured by the proper application of complete written procedures and standards of procurement such as pre and post qualification procedures; pre and post bid conference procedures; bid evaluation procedures; and bid challenge procedures. In addition BSI Group, (2008) points out that professionalization of public procurement, institutional and professional capacity, extent of e- procurement, and the performance of procurement department indicate the level of efficiency. Insufficient professionalism of designers may translate into poor planning, budgeting and risk management for procurement (Kerry \& Phoebe, 2006), leading to unnecessary delays and cost overruns for projects. In other words, designers and contractors are not necessarily well prepared to keep up with professional standards. Furthermore, these professionals may not necessarily be aware that their acts are unethical or may bias the process which can lead to conflict-of -interest situations and sometimes corruption (OECD, 2007).

Efficiency in use of resources needs to be monitored well by the contractors. Efficiency is the productive use of resources, that is, the ability to do something well or to achieve a desired result without wasted energy or effort. This is about ensuring value for money (Stansbury, 2005). Inefficiency occurs when the contractor becomes obliged (say, by consulting engineers) to forfeit well prepared work plans for less efficient techniques which ultimately compromise on quality. United Nations Development Programme, (2009) states that efficiency measures the extent to which there is maximum utilization of available resources to achieve the intended results. In assessing efficiency, a project evaluation might explore the extent to which resources are being used to produce the intended outputs and how resources could be used more efficiently to achieve the intended results (IFAD, 2009).

Evaluating effectiveness of project activities deters cases of abandoned and incomplete construction projects. Effectiveness is a measure of the extent to which the 
initiative's intended results (outputs or outcomes) have been achieved or the extent to which progress toward outputs or outcomes has been achieved. Evaluating effectiveness in project evaluations involves an assessment of cause and effect - that is, attributing observed changes to project activities and outputs. Assessing effectiveness involves three basic steps: Measuring change in the observed output or outcome, attributing observed changes or progress toward changes to the initiative (project evaluation) and judging the value of the change (positive or negative) (UNDP, 2009).

An evaluating of construction sustainability involves assessing the extent to which relevant social, economic, political, institutional and other conditions are present and, based on that assessment, making projections about the capacity to maintain, manage and ensure the development results in the future (UNDP, 2009). Sustainable construction implies that sustainable development strategies are applied to the entire construction process from planning, design and construction of buildings until project closure. This is because the aim of sustainable construction is to restore and maintain a balance between the natural and built environments, and establish buildings that maintain and promote human dignity and enhance economic development (CIB \& UNEP-IETC, 2002).

Public sector housing programs are characterized by doubtful quality, generally unimaginative planning and design, low market image, high client dissatisfaction, poor land management records, low land costs and low expectations of profit, offset by organizational inefficiency. In the rush to provide better housing and improved services, communities are sometimes relocated to remote sites that inhibit the social processes that facilitate cohesive communities and settlements. In Africa, single-purpose land use, low densities, long distances from work centres and inadequate public transport are some of the urban level unsustainability issues related to such interventions. In Asia and Latin America, issues such as a lack of formal low-income housing schemes in some countries, and the high population densities in housing schemes, create a different set of problems.

The question most often asked by service providers in the construction sector is whether there is a market for sustainability. It is the role of clients - from the individual buying a wood-treatment product to the government putting out tenders for infrastructure development - to demand products and services that support sustainable construction and thus create this market. For this, clients have to become informed customers, adopt mechanisms that will release funding for possible additional costs, form partnerships to leverage change, change their procurement systems and monitor the impact of their choices (CIB \& UNEP-IETC, 2002).

There is evidence that highly sustainable buildings can be produced at little or no additional costs, provided sustainability is designed in from the outset (Borough, 2012).
Therefore, from the foregoing, it is crucial for the construction project team, at some extent, to measure its performance on the activities or sub-processes performed throughout the construction project. Quality of a project can be considered as a result of the process as well as the presence of the process (Bai and Yang, 2011). For a project team to be effective, it is important for team members to understand and accept the quality measurement or indicators identified for the project.

\subsection{Theoretical Framework}

Consequentialism is probably the most commonly adopted ethical theory in construction projects. In consequentialism, an activity is morally right if the effects of that activity are more positive and desirable than undesirable. As long as an activity produces some desirable results, it is considered ethically right. One tool often used in engineering and construction projects in terms of consequential approach is a cost-benefit analysis which determines the feasibility of a project. Three divisions of consequentialism emerge (Internet Encyclopedia of Philosophy, 2003).One is ethical egoism in which behaviour is morally right if its results are more desirable only to the party doing that action. The second is ethical altruism where behavior is considered morally right if it yields more favourable effects to everyone with the exception of the agent. Third is utilitarianism whereby an action is ethically right if its consequences are more favourable to all people. Additionally, an action is acceptable if it yields maximum total utility universally.

This study argues that ethical egoism is likely to greatly cause unethical practices in building construction projects as actions are self-centred and works against the principle of beneficence. Ethical Altruism on the other hand will be in the interest of everyone else except the agent (contractor/consultant), who as a result will act not out of will but to please everyone else. In a similar manner, Audi (2004) argues that this does not bring maximum benefit to the agent (contractor/consultant), who becomes the casualty as he acts to satisfy all other project practitioners at the expense of self and therefore works against the principles of beneficence and justice. In this regard, a consideration of utilitarianism that stems from consequentialism is in accordance with traditional norms in almost all societies and satisfies the principle of beneficence. This is so because when an action is favourable to everyone including the contractor, then there is no casualty and a balance is struck between behavior and response. This upholds the principles of respect, beneficence and justice.

Similarly, Beauchampp (1996) states that virtue and deontological theories are geared towards appropriate ethical approaches to issues since good habits and obligation to do right both trigger favourable actions rooted in Utilitarianism. Such favourable actions are in harmony with the principles of beneficence and justice which require that no harm is done to a party (Beauchampp et al., 2001) and if this is inevitable, due compensation must be made (Andrews, 1989). In this regard, because the contractor is the party responsible for the 
construction of the residential building, it is the party that is ultimately liable to individual property owners for the harm that the operation of that building causes to them.

\section{RESEARCH METHODOLOGY}

Mixed methods research was used. It is an attempt to legitimate the use of multiple approaches in answering research questions, rather than restricting or constraining researchers' choices (that is., it rejects dogmatism). It is an expansive and creative form of research, not a limiting form of research. It is inclusive, pluralistic, and complementary, and it suggests that researchers take an eclectic approach to method selection and the thinking about and conduct of research (Johnson and Onwuegbuzie, 2004). It is oriented 'toward solving practical problems in the "real world" (Feilzer, 2010) rather than on assumptions about the nature of knowledge.

The research designs used in this study were descriptive survey design and correlational research design. The choice of these two research designs was informed by the fact that descriptive and inferential data analyses are required in this study. Shield and Rangarjan (2013) indicate that descriptive survey is used to describe characteristics of a population or a phenomenon being studied. Creswell (2012) indicates that correlational research design is the measurement of two or more factors to determine or estimate the extent to which the values for the factors are related or change in an identifiable pattern. Creswell (2012) indicates that correlational research design is the measurement of two or more factors to determine or estimate the extent to which the values for the factors are related or change in an identifiable pattern.

The target population was all the 228 NCA1, 170 NCA2, 188 NCA3, 497 NCA4, 421 NCA5, 632 NCA6, 682 NCA7 and 561 NCA8 registered contractors, giving a total of 3379 contractors. The target population was therefore all the 228 NCA1, 170 NCA2, 188 NCA3, 497 NCA4, 421 NCA5, 632 NCA6, 682 NCA7 and 561 NCA8 registered contractors, giving a total of 3379 contractors.

Stratified random sampling was thereafter employed to obtain individual respondents for the study. For the purpose of this study a census was used in three categories of the target population, namely, the NCA management, NBI management and the consultants.

The researcher used questionnaires for all the contractors and consultants and interview guides for representatives of NCA and NBI management.

Data collection from the contracting and consulting firms was done with the aid of research assistants. This approach was hoped to improve the rate of return of the questionnaires. Four research assistants were engaged. Each of the research assistants was assigned several engineering firms. Prior to deploying the research assistants for field work, the researcher trained the research assistants on research ethics as well as on the items in the research instruments to the extent that they can comfortably and independently clarify queries raised by respondents. A follow up time schedule was agreed upon and drawn between the researcher and the research assistants to guide supervision of the research progress. The research assistants were also equipped with a copy of the cover letter permitting them to collect data on behalf of the researcher.

\section{FINDINGS}

The researcher collected data from a total of 288 respondents which consisted of 67 consultants, 17 NCA and $12 \mathrm{NBI}$ officers in the management teams and 192 NCAs. Questionnaires were sent to all the 288 respondents out of which 222 questionnaires were filled and returned representing a response rate of seventy seven point one per cent $(77.1 \%)$. This response rate was considered adequate for analysis. According to Awino (2011), a response rate of 65 percent is acceptable for such studies. Out of 132 of the respondents, $66.7 \%$ indicated that they were male, while $33.3 \%$ they were female. This implies that majority of the respondents were male indicating a gender disparity in the construction industry towards females.

Various assumptions were made about variables during statistical tests. This was to ensure that the findings were worth using in decision-making. Failure to meet these assumptions would lead to Type I and Type II errors. In this study, normality was tested using Kolmogorov-Smirnov Test and the Shapiro-Wilk Test. The normality of the variables was also done and the study determined that all the variables had a fairly good fit in the normal distribution.

The weighting criteria of responses of Likert -type data assumed an equidistance of 0.8 whereby Strongly Disagree (SD) $1<\mathrm{SD}<1.8$; Disagree (D) $1.8<\mathrm{D}<2.6$; Neutral $(\mathrm{N})$ $2.6<\mathrm{N}<3.4$; Agree (A) 3.4<A $<4.2$; and Strongly Agree (SA) $4.2<\mathrm{SA}<5.0$. Theoretical literature linked ethical concerns in contract negotiation with quality of building projects.

Both theoretical and empirical review indicated that ethical concerns in project monitoring and evaluation influence quality of residential buildings construction projects. Respondents were asked to indicate the extent to which they were in agreement with statements regarding ethical concerns in project monitoring and evaluation of residential buildings construction projects.

Respondents were asked to indicate the extent to which compliance with work plan was assessed on site. The mean score was 3.6061 while the standard deviation was 1.1949.This result indicates that the majority of the respondents agreed that compliance with work plan was assessed on site. This suggests that in several instances, a consulting engineer visits the site to assess compliance with work plan. Monitoring and evaluation is a continuous process throughout the project cycle and the consulting engineer should frequent the site to assess progress. Engaging an independent professional to monitor and evaluate the work plan promotes efficiency and effectiveness of the operations thereby ensuring quality 
standards. This agrees with the views of Enshassi (1996) who stressed on the need to observe projects promptly and at regular intervals. This is of great significance in the attainment of quality and customer satisfaction.

The researcher sought to establish the frequency of site visits to assess conformity to the work plan. The mean score was 3.101 while the standard deviation was 0.9068 .This result indicates that the majority of the respondents were neutral on whether site visits were done frequently to assess conformity to the work plan. This suggests that site visits by the consulting engineers were not frequent during project implementation. Site visits help to monitor and control work in progress and where such visits are not frequent, deviations from set standards may not be realized in time early enough to correct them. Enshassi (1996) stresses on the need to observe projects promptly and at regular intervals. IUCN (2000) pointed out that regular monitoring of project progress will concentrate greater effort on the set output indicators and targets. This is of great significance in the attainment of quality and customer satisfaction. Where deviations from the expected results are noted, effort is made to correct them and this should be done on a regular basis. However, all effort should be made to produce 'right-first-time' which counters the reasoning that one builds to the minimum level of quality and later repair any faulty work (Tricker, 2008). Such reasoning works against Virtue theory which places emphasis on good character that would witness consistency in pursuit of quality in project undertakings.

Respondents were asked to indicate the extent to which quality of building materials was frequently tested on site. The mean score was 3.434 while the standard deviation was 1.3034.This result indicates that the majority of the respondents agreed that quality of building materials was frequently tested on site. Failure to test the materials for quality may tempt the contractor to buy cheap, substandard materials to save on cost and increase his profit. Bai and Yang (2011) expressed a similar opinion that the evaluation of process performance can help find questions in the enforcement of construction projects, determining the reasons for the questions and correcting the errors in the practice in time to improve management's performance of construction project. Failure to test the materials for quality would therefore be unethical and would culminate in compromise of quality buildings.

The researcher sought to determine the extent to which findings of assessment done during site visits were documented in progress reports. The mean score was 3.070 while the standard deviation was 0.9533 .This result indicates that the majority of the respondents were neutral that assessment done during site visits were documented in progress reports. Such a report includes a track of milestones attained in construction work. Findings of assessment done by consulting engineers should be documented in progress reports to enable the contractor and his team correct any deviations observed. Deviations noted in project performance should be corrected immediately. It's against such documented reports that a law suit can be initiated against the contractor if errors documented are ignored and cause a risky situation such as cracks and collapse of buildings. This agrees with the views of Armstrong (2005) who pointed out that construction errors once detected should be noted down and revealed to the concerned parties in order to pave way for the necessary correction. The study findings are as illustrated in the table below:

Means and Standard Deviations for influence of Monitoring and Evaluation

\begin{tabular}{|c|c|c|c|c|}
\hline & $\mathrm{N}$ & Mean & S.D & $\mathrm{CV}$ \\
\hline $\begin{array}{l}\text { a. Monitoring and evaluation of } \\
\text { building construction projects is } \\
\text { important }\end{array}$ & 198 & 4.2556 & 0.5739 & 0.3689 \\
\hline $\begin{array}{l}\text { b. I am satisfied with the level of } \\
\text { monitoring and evaluation done } \\
\text { on our building construction } \\
\text { projects }\end{array}$ & 198 & 3.4040 & 1.2126 & 0.5044 \\
\hline $\begin{array}{c}\text { A sustainability champion is } \\
\text { often found on site }\end{array}$ & 198 & 2.6111 & 1.1442 & 1.7015 \\
\hline $\begin{array}{c}\text { d. Compliance with work plan is } \\
\text { assessed on site }\end{array}$ & 198 & 3.6061 & 1.1949 & 0.4585 \\
\hline $\begin{array}{l}\text { e. Site visits are done frequently } \\
\text { to assess conformity to the } \\
\text { work plan }\end{array}$ & 198 & 3.1010 & 0.9068 & 0.4316 \\
\hline $\begin{array}{c}\text { f. Quality of building materials is } \\
\text { frequently tested on site }\end{array}$ & 198 & 3.4343 & 1.3034 & 0.5354 \\
\hline $\begin{array}{l}\text { g. Quality of building materials is } \\
\text { sometimes found to have been } \\
\text { compromised }\end{array}$ & 198 & 3.2929 & 0.9533 & 0.4157 \\
\hline $\begin{array}{c}\text { h. Findings of assessment done } \\
\text { during site visits are } \\
\text { documented in progress reports }\end{array}$ & 198 & 3.0707 & 0.9533 & 0.4604 \\
\hline $\begin{array}{l}\text { i. A report on milestones attained } \\
\text { in construction work is captured } \\
\text { in the progress reports }\end{array}$ & 198 & 3.0657 & 0.5145 & 0.2491 \\
\hline $\begin{array}{cc}\text { j. } & \begin{array}{c}\text { Deviations noted in project } \\
\text { performance are corrected } \\
\text { immediately }\end{array} \\
\end{array}$ & 198 & 3.2323 & 0.9855 & 0.4415 \\
\hline Composite Results & 198 & 3.337 & 1.472 & 0.5567 \\
\hline
\end{tabular}

The composite mean score for this section stands at 3.3374, the standard deviation at 1.4742 and the coefficient of variation at 0.5567 . This reveals that on average the respondents moderately agreed with influence of project monitoring and evaluation of residential building construction projects. Monitoring and evaluation of building construction projects are important. Huemann (2004) stated that an accreditation is an external evaluation based on defined and public known standards. Accreditation was originally established to support customer protection. Clients can be protected by certification, inspection, and testing of products and by manufacturing under certified quality systems. Clients need confidence in the certification, inspection, and testing work carried out on their behalf, but that they cannot check for themselves. 


\section{Inferential Analysis of Influence of Project Monitoring and} Evaluation on Quality of Residential Buildings Construction Projects

The objective of the study was designed to establish the relationship that exists between project monitoring and evaluation and quality of residential building construction projects. The literature that was reviewed in this study as well as theoretical reasoning associated project monitoring and evaluation with quality of residential buildings. Indicators of project monitoring and evaluation in the study were compliance with work plan, assessment of quality of building materials on site availability of progress reports and application of M \& E findings. Quality of residential building construction projects on the other hand was indicated by status of project audit, adequacy of minutes of quality meetings, status of testing reports, availability of check sheets and status of approval documents. Indications from both the theoretical and empirical literature pointed to a positive significant influence between project monitoring and evaluation and quality of residential buildings construction projects.

\section{Correlation Analysis}

Pearson Product Moment correlation coefficient was used to assess the strength and direction of the relationship between monitoring and evaluation and quality of residential buildings construction projects.

The Pearson's Product Moment Correlation coefficients showed the value of $r=0.409$. Shirley et al. (2005) indicates that for a weak correlation, " $\mathrm{r}$ " ranges from +0.10 to +0.29 ; in a moderate correlation, " $\mathrm{r}$ " ranges between +0.30 and + 0.49 ; while in a strong correlation, " $r$ " ranges from +0.5 and + 1.0. The positive or negative sign points to the direction of the relationship. It can therefore be argued that for $r<0.5$, there was a moderate correlation between the two variables under investigation. The results are shown in the table below:

Correlation Results for influence of Monitoring and evaluation

\begin{tabular}{|c|c|c|cc|}
\hline Model & $\mathrm{R}$ & $\begin{array}{c}\mathrm{R} \\
\text { Square }\end{array}$ & $\begin{array}{c}\text { Adjusted R Square } \\
\text { the Estimate }\end{array}$ \\
\hline & $.409^{\mathrm{a}}$ & .167 & .164 & .38096 \\
\hline \multicolumn{5}{|c|}{. Prandard Error of } \\
\hline
\end{tabular}

Since $r=0.409$ in this case, then there was a moderate positive significant correlation between ethical concerns in monitoring and evaluation and quality of residential buildings. In this case, the adjusted R-squared is 0.164 . This means that monitoring and evaluation variable explains $16.4 \%$ variations in the dependent variable (quality of residential buildings).This means that there might be many factors that can explain variations in quality. Hence, $83.7 \%$ of the variation in quality cannot be explained by monitoring and evaluation. Therefore other variables could be having more influence on quality.

\section{Test of Hypothesis}

Analysis of Variance (ANOVA) was used to test the hypothesis. The study calculated the ANOVA coefficient between the independent variable, monitoring and evaluation and the dependent variable, quality of residential building projects. The significant level of testing the hypothesis was 0.05 .

\section{Hypothesis three that the study tested was:}

$H_{0}$ : There is no significant influence of monitoring and evaluation on quality of residential buildings

The table below shows results of the relationship between monitoring and evaluation and quality of residential buildings.

ANOVA ${ }^{a}$ Results for Influence of Monitoring and evaluation

\begin{tabular}{|c|c|c|c|c|c|c|}
\hline \multicolumn{2}{|l|}{ Model } & $\begin{array}{c}\text { Sum of } \\
\text { Squares }\end{array}$ & df & $\begin{array}{c}\text { Mean } \\
\text { Square }\end{array}$ & F & Sig. \\
\hline Regression & 7.223 & 1 & 7.223 & 49.770 & $.000^{\mathrm{b}}$ \\
\hline Residual & 32.045 & 221 & .145 & & \\
\hline Total & 39.268 & 222 & & & \\
\hline \multicolumn{7}{|c|}{ a. Dependent Variable: quality of residential building construction } \\
projects \\
\hline \multicolumn{7}{|c|}{ b. Predictors: (Constant), monitoring and evaluation } \\
\hline
\end{tabular}

From the table $F$ value is 49.770 and $P$ value is 0.000 . At 0.05 level of significance and $95 \%$ level of confidence this is statistically significant as the P-Value is lower than 0.05 . The study therefore rejected the null hypothesis meaning that there was a significant relationship between monitoring and evaluation and quality of residential buildings in Nairobi County.

These findings concurred with the study of Leonard (2008) who observed that reduced subcontractor responsibility assists in improving quality among construction projects. He pointed out that poor on-site monitoring and feedback as well as poor planning and scheduling are major factors in project quality performance.

\section{Regression Modelling}

Linear regression was used for modelling the relationship between monitoring and evaluation and quality of residential buildings

Regression model was represented as

$\mathrm{Y}=\mathrm{a}+\beta \mathrm{X}_{1}+\varepsilon$

Quality of residential buildings construction projects $=\mathrm{f}$ (monitoring and evaluation).

The table below shows the regression model summary of analysis of influence of monitoring and evaluation on quality of residential buildings 


\section{Coefficients for Influence of Monitoring and evaluation}

\begin{tabular}{|c|c|c|c|c|c|}
\hline \multirow{2}{*}{ Model } & \multicolumn{2}{|c|}{$\begin{array}{c}\text { Unstandardized } \\
\text { Coefficients }\end{array}$} & $\begin{array}{c}\text { Standa } \\
\text { rdized } \\
\text { Coeffi } \\
\text { cients }\end{array}$ & \multirow{2}{*}{$\mathrm{T}$} \\
\cline { 2 - 5 } & $\mathrm{B}$ & $\begin{array}{c}\text { Std. } \\
\text { Error }\end{array}$ & Beta & \\
\hline & (Constant) & 3.414 & .153 & & 22.279 \\
\hline & $\begin{array}{c}\text { Monitoring and } \\
\text { Evaluation }\end{array}$ & .242 & .034 & .409 & 7.055 \\
\hline
\end{tabular}

a. Dependent Variable: Quality of residential building construction projects

Based on the analysis, Y intercept was 3.414 while coefficient of the independent variable (monitoring and evaluation) was 0.242 . Therefore, by substituting the beta value and the constant term, the proceeding regression model was:

$\mathrm{Y}=3.414+0.242 \mathrm{X}_{1}+\varepsilon$

The coefficient of monitoring and evaluation $\left(\mathrm{X}_{1}\right)$ of 0.242 refers to the elasticity of quality of residential buildings due to changes in monitoring and evaluation. The coefficient of 0.242 implies that if monitoring and evaluation increase by 100 percent, quality will improve by 24.2 percent. This agrees with a study by Mawenya (2008), who stated there exist a relationship between quality of construction project with management and evaluation in that the level of efficiency in public procurement is basically measured by the proper application of complete written procedures and standards of procurement such as pre and post qualification procedures; pre and post bid conference procedures; bid evaluation procedures; and bid challenge procedures. Borough (2012) observes that it is crucial for the construction project team, at some extent, to measure its performance on the activities or sub-processes performed throughout the construction project.

In addition BSI Group, (2008) points out that professionalization of public procurement, institutional and professional capacity, extent of e- procurement, and the performance of procurement department indicate the level of efficiency. Insufficient professionalism of designers may translate into poor planning, budgeting and risk management for procurement (Kerry \& Phoebe, 2006), leading to unnecessary delays and cost overruns for projects. In other words, designers and contractors are not necessarily well prepared to keep up with professional standards. Furthermore, these professionals may not necessarily be aware that their acts are unethical or may bias the process which can lead to conflict-of -interest situations and sometimes corruption (OECD, 2007).

\section{CONCLUSION}

The study concludes that conducting monitoring and evaluation leads to an increase in quality of residential building construction projects. The researcher concludes that consciously considering in monitoring and evaluation would guarantee sustainable construction as this would ensure compliance with work plan, assessment of quality of building materials on site, availability of progress reports and application of Monitoring and Evaluation findings. This is because the aim of sustainable construction is to restore and maintain a balance between the natural and built environments, and establish buildings that maintain and promote human dignity and enhance economic development.

\section{RECOMMENDATION}

Ethical principles of respect, beneficence and justice in monitoring and evaluation should always be upheld in the entire construction process from planning, design and construction of buildings until project closure. This would ensure that the projects restore and maintain a balance between the natural and built environments, and establish buildings that maintain and promote human dignity and enhance economic development. Project implementation process should be overseen by a competent consultant to ensure good supervision/inspection. This will also ensure that the project plan is followed to the letter and all the amendments done at the right time and in an appropriate way to ensure successful project delivery. Developers/ project champions/ owners should ensure construction projects are not starved of finances. This will ensure that construction projects do not stall.

\section{REFERENCES}

[1] Alsagour M. (2014).Factors and Steps to Termination of Project. International Journal Of Management and Commerce Innovations ISSN 2348-7585 (Online)Vol. 2, Issue 1, Pp: (19-21).

[2] Audi, R.( 2004). The good in the right: A theory of good and intrinsic value, Princeton: Princeton University Press.

[3] Bai, J., and Yang, X. (2011). "Research on construction project process performance measurement." Industrial Engineering and Engineering, 1915-1918.

[4] Beauchamp TL, Childress JF. (2001). Principles of Biomedical Ethics 5th ed. Oxford: Oxford University Press.

[5] Beauchamp, TL. (1996). Moral foundations. In: Coughlin, SS.; Beauchamp, TL., 1996. Ethics and Epidemiology. New York: Oxford University Press; p. 24-52.

[6] Beauchamp, TL.; Childress, JF. 1994. Principles of biomedical ethics. Vol. 4. New York: Oxford University Press.

[7] Borough L. (2012). Good Practice Guidance: Sustainable Design and Construction- Development Management Development Plan Document (DPD)

[8] Bowen, P., A. Akintoye, R. Pearl, and P.J. Edwards (2007). Ethical behaviour in South African construction industry. Construction Management and Economics, Vol. 25, pp 631-648.

[9] BSI Group,( 2008). Improving the efficiency of Public Procurement: The Role of standards, Available at www.bsigroup.com (Retrieved October 5, 2015).

[10] Chandrupatla R., (2014). Quality and Reliability in Engineering. Cambridge University Press. 978-0-521-51522-1

[11] CIB \& UNEP-IETC (2002). Agenda 21 for Sustainable Construction in Developing Countries. A discussion document. Building and Construction Technology. South Africa.

[12] Creswell, J. W. (2009). Research design: Qualitative and mixed methods approaches. London: SAGE Publications. Retrieved from http://oscarjaramillo.cl/wp-content.

[13] Enshassi, A. (1996). A Managing and Controlling System in Managing Infrastructure Projects. Building Research and Information Journal, 24(3): 163-189.

[14] Enshassi, A. (1996). A Managing and Controlling System in Managing Infrastructure Projects. Building Research and Information Journal, 24(3): 163-189. 
[15] Faridi, A.; El-Sayegh, S. 2006. Significant factors causing delay in the UAE construction industry, Construction Management and Economics 24(11): 1167-1176.

[16] Hanson, D.; Mbachu, J.; Nkando, R. 2003. Causes of client dissatisfaction in the South African building industry and ways of improvement: the contractors' perspectives, in CIDB, South Africa.

[17] Huemann, M., (2004). Improving Quality in Projects and Programs: The Wiley Guide to Managing Projects. Wiley \& Sons. Vienna.

[18] Hutchinson J. (2014). The 10 Worst High-Rise Building Collapses in History https://www.bestonlineengineeringdegree.com/the-10worst-high-rise-building-collapses-in-history/Retrieved on $24 / 04 / 2017$

[19] IUCN (2000). International Union for Conservation of Nature and Natural Resources. Introduction to Key Concepts, Approaches and Terms Working Draft Version 1 -Global Monitoring and Evaluation Initiative

[20] Johnson B. and Onwuegbuzie A. J. (2004). Mixed Methods Research: A Research Paradigm Whose Time Has Come. Educational Researcher, Vol. 33, No. 7 (Oct., 2004), pp. 14-26 American Educational Research Association.

[21] Kerry L. and Phoebe E. (2006). Ethical Behaviour in the construction procurement process. Icon. Net Pty Ltd. Brisbane, Australia.

[22] Mbachu, J.andNkando, R. (2007). Factors constraining successful building project implementation in South Africa, Construction Management and Economics 25(1): 39-54.

[23] Newton P.,2015. Project Quality: Project Skills. Retrieved on 4/02/2017 from http://www.free-management-ebooks.com.

[24] OECD (2007). Integrity In Public Procurement Good Practice From A To Z, Paris, France.

[25] PM4DEV (2016). Project Quality: Project Management for Development of Organizations: A Methodology to Manage
Development Projects for International Humanitarian Assistance and Relief Organizations.

[26] Rumane, A.R.2011. Quality management in construction projects. Boca Raton, FL: CRC Press.

[27] Sambasivan, M. and Soon, Y. (2007). Causes and effects of delays in Malaysian construction industry, International Journal of Project Management, 25 (5), 517-526

[28] Shakantu, W. (2006). Corruption in the construction industry, forms, susceptibility and possible solutions. Cape Town: University of Cape Town.

[29] Shield, P. and Rangarjan, N. (2013). A Playbook for Research Methods:Integrating

Conceptual Frameworks and Project Management. Stillwater, OK: New Forums Press.

[30] Stansbury, N. (2005) Exposing the foundations of corruption in construction. In Global Corruption Report, 2005. Special Focus: Corruption in Construction and Post Conflict Reconstruction.

[31] Transparency International (2005a). What are the Effects of Corruption? London: Transparency International.

[32] Tricker, R. (2008). ISO 9001:2000 for small business.Thirdeditioned. Oxford: Butterworth-Heinemann.

[33] UNDP (2009). Handbook on Planning, Monitoring and Evaluating for Development Results. New York. Retrieved on 15/5/2016 from: http://www.undp.org/eo/handbook

[34] UNDP (2009). Handbook on Planning, Monitoring and Evaluating for Development Results. New York. Retrieved on 15/5/2016 from: http://www.undp.org/eo/handbook

[35] Vee, C, and Skitmore, M (2003) Professional ethics in the construction industry. Journal of Engineering, Construction and Architectural Management, 10 (2), 117-127.

[36] Zhou, P.X. W. (2006). Strategies for Minimising Corruption in the Construction Industry in China. Journal of construction in Developing Countries, Vol. 11, No.2. 